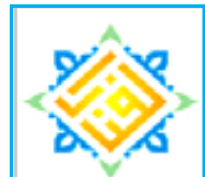

AL-FANAR

Jurnal Ilmu Al-Quran dan Tafsir
Volume 4, Nomor 2, 2021, hlm. 135-156

P-ISSN: 2622-2280 | E-ISSN: 2622-4658

https://ejurnal.iiq.ac.id/index.php/alfanar

\title{
Indonesia Guidelight Project dan Tafsir Audiovisual: Tinjauan atas Metodologi Tafsir dan Kontribusinya di Masa Pandemi
}

\author{
Mamluatun Nafisah dan Nur Azizah Trijayanti \\ Institut Ilmu Al-Qur'an (IIQ) Jakarta \\ mamluatun@,iiq.ac.id dan nurazizahtrijayanti@gmail.com
}

DOI: $10.33511 /$ alfanar.v4n2.135-156

Submitted: 2021-06-12, Revised: 2021-07-09, Accepted: 2021-08-17

\begin{abstract}
.
This paper departs from the many platforms on social media that offer virtual AlQur'an learning facilities, especially during the pandemic. One of the platforms on social media that facilitates virtual Al-Qur'an learning is the Indonesia Guidelight Project. To find out how the methodology for audiovisual interpretation of the Indonesia Guidelight Project is and how the contribution and reception of participants to the study is, the author uses the phenomenological approach initiated by Edmund Husserl and the interpretation approach. The results of this study conclude that the Guidelight audiovisual interpretation provides a positive contribution to the wider community so as to increase their understanding of the content of the Quran and become a better person. In addition, if you look at the methodological aspect, the audiovisual interpretation of Guidelight is substantially informative by presenting resource persons who have appropriate competence as exegetes. It's just that the form of interpretation uses a textual approach.
\end{abstract}

Keywords: Audiovisual Interpretation, Guidelight, Virtual

\section{Abstrak.}

Tulisan ini berangkat dari banyaknya platform di media sosial yang menawarkan fasilitas belajar Al-Qur'an secara virtual, khususnya di masa pandemi. Salah satu platform di media sosial yang memfasilitasi pembelajaran Al-Qur'an secara virtual adalah Indonesia Guidelight Project. Untuk mengetahui bagaimana metodologi atas tafsir audiovisual Indonesia Guidelight Project dan bagaimana kontribusi serta resepsi peserta atas kajian tersebut, penulis menggunakan pendekatan fenomenologi yang digagas oleh Edmund Husserl dan pendekatan tafsir. Hasil penelitian ini menyimpulkan bahwa Tafsir audiovisual Guidelight memberikan sumbangsih yang positif bagi masyarakat secara luas sehingga menambah pemahaman mereka terhadap kandungan Al-Qur'an dan menjadi pribadi yang lebih baik. Selain itu jika melihat dari aspek metodologis, tafsir audiovisual Guidelight secara substansi cukup informatif dengan menghadirkan narasumber yang memiliki kompetensi yang layak sebagai mufasir. Hanya saja bentuk penafsirannya lebih banyak menggunakan pendekatan tekstual.

Kata Kunci: Tafsir Audiovisual, Guidelight, Virtual 
Indonesia Guidelight Project dan Tafsir Audiovisual: Tinjauan atas Metodologi Tafsir dan Kontribusinya di Masa Pandemi

\section{PENDAHULUAN}

Di tengah perkembangan teknologi informasi saat ini, metode belajar membaca maupun memahami kandungan Al-Qur'an sangatlah beragam. Banyak platform di media sosial yang menawarkan fasilitas belajar Al-Qur'an secara praktis dan mudah dilakukan. Apalagi sejak pandemi, dengan adanya kebijakan pembatasan kegiatan secara fisik, maka kajian Al-Qur'an secara virtual menjadi pilihan.

Salah satu aplikasi yang memfasilitasi sarana tatap muka secara virtual melalui video conference adalah Zoom Cloud Meeting. Aplikasi ini dapat menampung hingga 1000 partisipan dalam satu pertemuan secara virtual dengan menggabungkan konferensi video, pertemuan online, obrolan, hingga kolaborasi seluler. Aplikasi ini pun banyak digunakan, ${ }^{1}$ termasuk dalam proses pembelajaran Al-Qur'an secara virtual.

Salah satu platform di media sosial yang memfasilitasi pembelajaran Al-Qur'an secara virtual adalah Indonesia Guidelight Project. Indonesia Guidelight Project merupakan komunitas yang mempunyai misi ingin mengembalikan Al-Qur'an sebagai pedoman bagi umat muslim yang akhir-akhir ini mulai terabaikan. Selain itu, mereka ingin mengajak muslim di seluruh Indonesia untuk menghafal, berpikir, memahami, dan mengimplementasikan nilai-nilai Al-Qur'an. ${ }^{2}$ Untuk mewujudkan misi tersebut, berbagai program dirancang oleh Guidelight dengan menghadirkan narasumber yang ahli dibidangnya. Tidak hanya itu, mereka juga mengajak para kaum millenial untuk belajar Al-Qur'an dengan menyelami makna yang terkandung di dalamnya.

Adanya fenomena di atas merupakan bentuk wajah baru kajian Al-Qur'an yang disuguhkan dan dikemas dengan teknologi digital atau yang dikenal dengan tafsir audiovisual. ${ }^{3}$ Penyebutan rekaman audiovisual kajian tafsir sebagai sebuah tafsir adalah karena dalam hal ini kajian tafsir telah berbentuk utuh dalam satu format media. Hal ini tidak jauh berbeda dengan kitab tafsir yang berisi berbagai kajian tafsir yang dituliskan dalam lembaran media kertas. Bahkan, tafsir audiovisual ini memiliki jangkauan audiens atau khalayak yang lebih luas dari pada kajian tafsir yang menggunakan media tradisional.

\footnotetext{
${ }^{1}$ Berdasarkan data yang dikutip dari Selular.id bahwa Eric S Yuan, CEO Zoom menyebutkan, pada Maret, penggunaZoom mencapai200jutapeserta rapatharian, baikgratis maupun berbayar. Padahal pada bulan Desember 2019, penguna harian berkisar mencapai 10 juta pengguna gratis dan premium. Lihat Yuni Riadi, “Zoom Capai 200 Juta Pengguna Harian”, dalam Selularid pada 3 April 2020, https:// selular.id/2020/04/zoom-capai-200-juta-pengguna-harian/ diakses pada 03 Agustus 2021. Selain itu, dalam sumber lain yaitu Kompas.com menyebutkan dalam laporan keuangan kuartal III-2020, Zoom melaporkan meraup pendapatan sebesar 777,2 juta dollar AS atau sekitar Rp 11 triliun. Jumlah ini naik signifikan sebesar 367 persen atau empat kali lipat, dibandingkan periode yang sama tahun lalu. Lihat Conney Stephanie, "Pandemi Covid-19, Pendapatan Zoom Naik Hampir 4 Kali Lipat", dalam Kompas.com, pada tanggal 1 Desember 2020, https:/tekno.kompas.com/read/2020/12/01/18120027/ pandemi-covid-19-pendapatan-zoom-naik-hampir-4-kali-lipat dan diakses pada 03 Agustus 2021.

${ }^{2}$ Ahmad Safe'i Ridwan, dkk., Indonesia Guidelight Project: A Beginning to Understand His Words, h. 1, tidak diterbitkan.

${ }^{3}$ Audiovisual berasal dari kata audible dan visible. Audible artinya dapat didengar dan visible artinya dapat dilihat. Dalam Kamus Besar Ilmu Pengetahuan, audio adalah hal-hal yang berhubungan dengan suara atau bunyi. Sementara visual adalah hal-hal yang berkaitan dengan penglihatan; dihasilkan atau terjadi sebagai gambaran dalam ingatan. Lihat Moh Syahri Sauma, "Ayat-Ayat Audiovisual dalam Perspektif Dakwah Virtual (Kajian Tafsir Dakwah)", Jurnal AnNida', Vol. 8, No. 2, 2020, h. 26.
}

136 | Al-Fanar: Jurnal Ilmu Al-Qur'an dan Tafsir 
Dalam kaitannya dengan kajian tafsir audiovisual, pada dasarnya belum banyak yang mengkaji tema tersebut. Misalnya saja Nafiisatuzzahro' yang berusaha menelisik lebih jauh bagaimana hasil dari keikutsertaan YouTube dalam kajian Al-Qur'an dan Tafsir. Menurutnya, aplikasi YouTube berhasil melahirkan bentuk tafsir baru, yaitu tafsir audiovisual, yang keberadaannya berimplikasi pada terbentuknya klasifikasi baru tafsir. ${ }^{4}$ Kajian serupa juga dilakukan oleh Moh. Azwar Hairul yang mengkaji metode penafsiran dan nuansa tafsir yang menjadi ciri khas dari Nouman Ali Khan dan sejauh mana efektivitas penafsirannya melalui YouTube mempengaruhi audiens tafsir. ${ }^{5}$ Hal yang sama juga dilakukan Ali Hamdan. Beliau berusaha menggali dimensi sosial dalam wacana tafsir audiovisual "Lebah Menurut Al-Qur'an dan Sains?" Kajian ini menggunakan persepktif analisis wacana kritis dengan kerangka analisa Dimensi Sosial ala Tuen van Dji. ${ }^{6}$ Penelitian sama juga dilakukan oleh Roudlotul Jannah yang menelaah bagaimana model tafsir pada akun Instagram@quranreview dan bagaimana implikasinya terhadap perkembangan studi Al-Qur'an dan Tafsir. ${ }^{7}$

Beranjak dari penelitian terdahulu tersebut, menurut penulis ada aspek yang belum dilihat oleh para peneliti sebelumnya, yakni menganalisa secara mendalam bagaimana metodologi tafsir audiovisual Guidelight dan resepsi para pesertanya atas kajian tersebut. Oleh karena itu, kehadiran penelitian ini sangat penting guna mengisi kekosongan tersebut. Namun, agar lebih spesifik, maka pertanyaan utama yang ingin dijawab dalam penelitian ini adalah bagaimana metodologi atas tafsir audiovisual Indonesia Guidelight Project dan bagaimana kontribusi serta resepsi peserta atas kajian tersebut?

Untuk menjawab pertanyaan tersebut, penelitian ini menggunakan dua pendekatan sekaligus, yaitu pendekatan fenomenologi yang digagas oleh Edmund Husserl, dimana pendekatan ini untuk memahami fenomena secara objektif, yang dalam hal ini adalah kajian tafsir Al-Qur'an yang dilakukan oleh Indonesia Guidelight Project dan resepsi pesertanya. Selain itu, penulis juga menggunakan pendekatan tafsir untuk mengidentifikasi dan menganalisa aspek metodologi penafsiran Guidelight.

\section{INDONESIA GUIDELIGHT PROJECT: KOMUNITAS YANG KONSEN MENDAKWAHKAN AL-QUR'AN MELALUI MEDIA SOSIAL}

Indonesia Guidelight Project merupakan komunitas yang bergerak di bidang pendidikan Al-Qur'an yang didesain secara khusus untuk memfasilitasi muslim Indonesia dalam meningkatkan kualitas ber-Quran-nya. Komunitas ini didirikan oleh Ahmad

\footnotetext{
${ }^{4}$ Nafiisatuzzahro', “Transformasi Tafsir Al-Qur'an di Era Media Baru: Berbagai Bentuk Tafsir Al-Qur'an Audiovisual di YouTube”, dalam Hermeneutik: Jurnal Ilmu Al Qur'an dan Tafsir, Vol. 12, No. 2, 2018, h. 32-65.

${ }^{5}$ Moh. Azwar Hairul, “Tafsir Al-Qur'an di YouTube Telaah Penafsiran Nouman Ali Khan di Channel Bayyinah Institute dan Quran Weekly", dalam Al-Fanar: Jurnal Ilmu Al-Qur'an dan Tafsir, Vol. 2, No. 2, 2019, h. 97.

${ }^{6}$ Ali Hamdan, "Dimensi Sosial dalam Wacana Tafsir Audiovisual: Studi atas Tafsir Ilmi, "Lebah Menurut al-Qur'an dan Sains," Lajnah Pentashihan Mushaf Al-Qur'an Kemenag RI di Youtube”, dalam Religia: Jurnal Ilmu-Ilmu Keislaman, Vol. 22, No. 2, 2019, h. 248-266.

${ }^{7}$ Roudlotul Jannah, “Tafsir Al-Qur'an Media Sosial: Studi Model Tafsir pada Akun Instagram @Quranreview”, Skripsi, UIN Maulana Malik Ibrahim Malang Tahun 2021.
} 
Indonesia Guidelight Project dan Tafsir Audiovisual: Tinjauan atas Metodologi Tafsir dan Kontribusinya di Masa Pandemi

Safe'i Ridwan ${ }^{8}$, Nur Rizkya Hanifa ${ }^{9}$ dan Resky Syam ${ }^{10}$. Wacana untuk mendirikan komunitas ini mulai tercetus ketika mereka menjalani masa-masa akhir kepengurusan sebagai pengurus inti Lembaga Dakwah Kampus Nasional (LDKN) Salam UI 22. Bersama dengan pengurus inti lainnya, mereka berencana untuk membuat sebuah 'proyek abadi' yang nantinya menjadi wadah untuk melanjutkan program-program dakwah meski sudah tidak tergabung di organisasi yang sama. Proyek ini diharapkan dapat dijalankan bersama sampai akhir hayat. ${ }^{11}$

Tepat pada tanggal 30 Maret 2020, Safe'i, Resky dan Hanifa mulai berdiskusi untuk merealisasikan wacana mereka. Tak butuh waktu lama, tanggal 3 April $2020 \mathrm{M}$ atau bertepatan dengan 9 Sya'ban $1441 \mathrm{H}$, komunitas ini resmi dibentuk dan diluncurkan melalui platform media sosial yaitu Instagram. ${ }^{12}$

Pemilihan nama "Guidelight" untuk komunitas ini terinspirasi dari Al-Qur'an, yakni dalam Surat Al-Jātsiyah ayat 20. Guidelight adalah penggabungan dari dua kata dalam bahasa Inggris, yaitu "Guide" yang berarti petunjuk dan "Light" yang berarti cahaya. Sehingga, dapat dimaknai sebagai cahaya yang memandu kehidupan. The Quran is \#MyFirstGuidance menjadi slogan dan identitas dari komunitas ini yang mengkampanyekan bahwa Al-Qur'an adalah petunjuk pertama dan utama dalam hidup. Sementara tagar \#Lightseeker yang berarti "pencari cahaya" menjadi identitas bagi setiap individu yang memilih Guidelight sebagai wadah mereka dalam mempelajari Al-Qur'an. ${ }^{13}$

Guidelight dibentuk atas beberapa faktor. Selain visi yang sama yang terbangun dalam LDKN Salam UI 22, terdapat juga faktor internal dari masing-masing

\footnotetext{
${ }^{8}$ Ahmad Safe'i Ridwan adalah alumni Program Studi Teknik Elektro Fakultas Teknik Universitas Indonesia angkatan 2015. Safe'i pernah menjabat sebagai Ketua Lembaga Dakwah Kampus Nasional (LDKN) Salam UI 22. Saat ini, Safe'i menjabat sebagai Founder dan Chief Learning Officer di Indoesia Guidelight Project.

${ }^{9}$ Nur Rizkya Hanifa adalah alumni Program Studi Manajemen Fakultas Ekonomi dan Bisnis Universitas Indonesia angkatan 2015. Saat ini Hanifa menjabat sebagai Co-Founder dan Chief Financial Officer di Indonesia Guidelight Project.

${ }^{10}$ Resky Syam adalah alumni Program Studi Gizi Fakultas Kesehatan Masyarakat Universitas Indonesia angkatan 2015. Selain menjadi Co-Founder Indonesia Guidelight Project, Resky juga menjadi Founder Guidelight Makassar.

11 Sebagaimana pengakuan Ahmad Safe'i Ridwan, bahwa "Ada dua prinsip yang selalu disampaikan oleh pembina kami di berbagai kesempatan. Beliau berpesan, bahwa sebagai seorang muslim, kita harus sadar betul bahwa kita membutuhkan pahala kebaikan yang tidak hanya diusahakan oleh diri kita sendiri. Dan sebagai seorang muslim, kita juga harus sadar betul, bahwa tidak ada pahala kebaikan yang lebih besar dibandingkan pahala orang-orang yang berjihad di jalan Allah. Hingga akhirnya terbesit dalam pikiran kami, apa yang akan kami lakukan selepas kepungurusan kami di Salam UI? Kontribusi apa yang bisa kami berikan untuk ummat ini? Apakah selepas Salam UI, sudah selesai pula tugas dakwah ini? Jikalau demikian, kemana dua prinsip yang katanya dipegang teguh selama ini? Melalui project ini, kami ingin menjaga agar hati ini tetap sehat, tetap subur, dan bertumbuh. Menjaga hati agar tetap peka, dan memiliki semangat untuk menyebarkan kebaikan seluas mungkin ke penjuru nusantara”. Wawancara dengan Founder Indonesia Guidelight Project, Ahmad Safe'i Ridwan pada hari Kamis, 22 Juli 2021, pukul 10.13 WIB.

12 Wawancara dengan Co-Founder Indonesia Guidelight Project, Nur Rizkya Hanifa pada hari Rabu, 21 Juli 2021, pukul 07.33 WIB.

${ }^{13}$ Wawancara dengan Founder dan Co-Founder Indonesia Guidelight Project, Ahmad Safe'i Ridwan dan Nur Rizkya Hanifa pada hari Kamis, 22 Juli 2021, pukul 20.00 WIB.
} 
pendiri maupun faktor eksternal yang melatarbelakanginya. Adapun faktor internal sebagaimana yang dikemukakan oleh Hanifa bahwa Syaikh Ali Hammuda ${ }^{14}$ menjadi sosok yang menginspirasinya untuk lebih dekat dengan Al-Qur'an. Ia menyadari bahwa mempelajari Al-Qur'an bukan hanya sekadar selesai memperbaiki bacaan, selesai menambah dan muroja' $a h$ hafalan, melainkan harus selalu ada peningkatan. Ia mendapat pencerahan bahwa Al-Qur'an adalah pedoman hidup yang sesungguhnya. Sebagai mahasiswi dari jurusan non-keagamaan, rasa antusias dan semangat itu ingin ia tularkan kepada pemuda-pemudi muslim lainnya. Ia memikirkan bagaimana caranya membentuk komunitas yang interaktif dan membuat orang-orang tergerak untuk mentransformasi pengetahuan menjadi amal nyata. ${ }^{15}$ Selain itu, ustadz Nouman Ali Khan yang merupakan CEO Bayyinah Institute dan ustadz Adi Hidayat, seorang pendiri Quantum Akhyar Institute dan Akhyar TV di berbagai ceramahnya membahas Al-Qur'an secara rinci mulai dari tafsir per kata, hikmah ayat dan seterusnya, juga menjadi inspirasi bagi ketiga pendiri Guidelight untuk membentuk komunitas yang menyediakan fasilitas pembelajaran Al-Qur'an secara lengkap. ${ }^{16}$

Sementara untuk faktor eksternal berdirinya Guidelight, yaitu: pertama, mereka melihat fenomena muslim khususnya di Indonesia yang banyak membaca Al-Qur'an tapi tidak mengerti isinya. Ada juga yang menghafal Al-Qur'an tapi tidak bertahan lama, dan tidak sedikit yang membaca serta menghafal banyak ayat tapi sama sekali tidak berpengaruh pada kualitas hidupnya. ${ }^{17} \mathrm{Kedua}$, fenomena awal pandemi Covid-19 yang melanda Indonesia sehingga mulai diberlakukan pembatasan sosial di berbagai sektor, termasuk perkantoran, pendidikan, akses kajian keislaman secara langsung, dan lain-lain. Hal ini tidak sedikit membuat sebagian orang merasa tertekan dan depresi. Melihat momentum Ramadhan di tengah pandemi menjadi peluang untuk menghubungkan orang-orang dengan kebutuhan yang sama, seperti ilmu dan sosialisasi dengan membentuk komunitas dengan berbagai program yang mewadahi kebutuhan tersebut. ${ }^{18}$

Untuk pencapaian Indonesia Guidelight Project Per Juli 2021 diantaranya telah mengadakan lebih dari 30 sesi program Online Course Tafsir Al-Qur'an Surat Pendek dan meluluskan 91 \#LightSeeker dari program Online Course Al-Qur'an serta telah memiliki lebih dari 14.000 pengikut di akun Instagram@guidelight.id. ${ }^{19}$ Selain itu,

${ }^{14}$ Ustadz Ali Hammuda adalah seorang pendidik dan penulis yang berasal dari Palestina tetapi dibesarkan di Inggris. Meskipun berprofesi sebagai arsitek/perencana, saat ini ia bekerja dengan Al-Manar (Cardiff) sebagai petugas program Islam di Inggris. Ali Hammuda dikenal sebagai penulis berbagai buku termasuk 'Origins of the Mosque of Cordoba' dan 'The End of Times', dan terus memberikan ceramah, kuliah, dan kelas reguler di seluruh negeri. Ia adalah seorang penulis reguler tentang isu-isu Islam untuk khalayak luas. (sumber: https:/muslimcentral.com/audio/ali-hammuda/)

${ }^{15}$ Wawancara dengan Co-Founder Indonesia Guidelight Project, Nur Rizkya Hanifa pada hari Rabu, 21 Juli 2021, pukul 07.33 WIB.

${ }^{16}$ Wawancara dengan Co-Founder Indonesia Guidelight Project, Nur Rizkya Hanifa pada hari Rabu, 21 Juli 2021, pukul 07.33 WIB.

${ }^{17}$ Ahmad Safe'i Ridwan, dkk., Indonesia Guidelight Project: A Beginning to Understand His Words, hlm. 1-2, tidak diterbitkan.

${ }^{18}$ Wawancara dengan Co-Founder Indonesia Guidelight Project, Nur Rizkya Hanifa pada hari Rabu, 21 Juli 2021, pukul 07.33 WIB.

${ }^{19}$ Lihat “About Guidelight.id: Let's Number Talks” dalam website resmi Indonesia Guidelight Project, https://guidelight.id/about/ diakses pada 30 Juli 2021. 
Indonesia Guidelight Project dan Tafsir Audiovisual: Tinjauan atas Metodologi Tafsir dan Kontribusinya di Masa Pandemi

Guidelight juga telah memiliki 32 superteam, ${ }^{20} 6$ diantaranya sebagai anggota core team (team inti) ${ }^{21}$ dan 26 lainnya tersebar di beberapa divisi. ${ }^{22}$ Pencapaian Guidelight yang lain juga terlihat dengan dibukanya secara resmi cabang pertama, yakni Guidelight Makassar tepat pada 2 Januari 2021 yang dikepalai oleh Resky Syam dan dibina oleh Ustadz Syamsuddin Nur. ${ }^{23}$ Sementara untuk memperluas jejaring, Guidelight memiliki banyak media sosial, seperti website (https://guidelight.id/), Instagram (@guidelight. id), YouTube (Guidelight), Spotify (\#ListenToTheLight Podcast), LinkedIn, ${ }^{24}$ dan email (admin@guidelight.id).

Harapan terbesar Indonesia Guidelight Project untuk jangka panjang diantaranya, ingin menjadi salah satu platform Al-Qur'an terbesar di Indonesia bahkan sampai internasional ${ }^{25}$. Bisa memfasilitasi pembelajaran Al-Qur'an bagi semua kalangan dengan mudah dan membuat semua orang tertarik untuk mempelajari Al-Qur'an tanpa rasa insecure. Bisa hadir di wilayah-wilayah lain di Indonesia untuk membumikan Al-Qur'an dan menyentuh semua kalangan serta usia. Termasuk para penyandang disabilitas. Selain itu, harapan lainnya adalah agar komunitas ini segera memiliki badan hukum. Meski sudah berbadan hukum, komunitas juga terus berjalan dan akan terus dikembangkan seperti ranah kesehatan, ekonomi, infrastruktur dan lain-lain yang mana semuanya bernafaskan Al-Qur'an. Terakhir, harapan besar yang disampaikan Safe'i Ridwan bahwa Indonesia Guidelight Project bisa menjadi wasilah dalam perjuangannya mendakwahkan agama Allah. ${ }^{26}$

\section{KONTRIBUSI GUIDELIGHT DAN RESEPSI PARA PESERTANYA}

Indonesia Guidelight Project pada awal terbentuknya memiliki tiga program. Pertama, Free Online Course Tafsir Al-Qur'an Surat Pendek. Kajian seri tafsir gratis yang diadakan 2-3 kali dalam sebulan dan membahas surat-surat yang sering dibaca ketika sholat. Program ini bertujuan untuk memfasilitasi masyarakat umum agar lebih memahami dan menghayati surat-surat pendek tersebut sehingga diharapkan dapat membantu meningkatkan kualitas kekhusyukan dalam sholat. Diperuntukan bagi semua usia dan diikuti rata-rata 100-200 orang tiap sesinya. Selain terdapat Whatsapp

${ }^{20}$ Panggilan untuk anggota tim di Guidelight.

${ }^{21}$ Ahmad Safe'i Ridwan (Founder \& Chief Learning Officer), Nur Rizkya Hanifa (Co-Founder \& Chief Financial Officer), Abyan Jadidan (Chief Operational Officer), Nurhikmah (Chief Mentorship Officer), Ahmad Wigo Prasetya (Chief Brand Officer) dan Syamsu Rijal Efendi (Chief Technology Officer).

22 Terdiri dari Content Development, Branding, IT Development, Online Community Development, Fundrising, dan Mentors \& Membership Development.

${ }^{23}$ Ada beberapa hal yang melatarbelakangi Guidelight Makassar dibentuk, diantaranya karena ada kesulitan untuk menyesuaikan perbedaan waktu, cara belajar, bahasa dan budaya antara peserta dari daerah Indonesia bagian Tengah khususnya Makassar dengan Guidelight pusat. Selain itu, agar di Makassar dan sekitarnya memiliki wadah untuk beajar Al-Qur'an.

${ }^{24}$ https://www.linkedin.com/company/indonesia-guidelight-project/

${ }^{25}$ Ekspansi secara usia dan cakupan (baik nasional dan internasional). Karena sejak awal Guidelight membuka program, sudah ada audiens dari Arab Saudi yang tertarik untuk mengikuti program di Guidelight.

${ }^{26}$ Wawancara dengan Founder Indonesia Guidelight Project, Ahmad Safe'i Ridwan pada hari Kamis, 22 Juli 2021, pukul 20.00 WIB.

140 | Al-Fanar: Jurnal Ilmu Al-Qur'an dan Tafsir 
Group khusus, peserta yang belum mendaftar juga bisa mengakses kajian di Channel YouTube Guidelight. ${ }^{27}$

Kedua, Quranic Webinar/Talkshow. Kajian tematik yang diadakan 1 kali sebulan dalam rangka meningkatkan kecintaan masyarakat umum terhadap Al-Qur'an. Mengangkat tema tentang kondisi-kondisi kekinian. Program ini telah dihadiri oleh para pembicara nasional serta para ahli di bidangnya. Tidak ada batasan usia dan ratarata diikuti lebih dari 200 orang. ${ }^{28}$

Ketiga, Online Course Al-Qur'an yaitu kelas intensif berbayar selama 1-2 bulan yang fokus membahas 1 surat. Di program ini peserta akan diajak untuk menghafal, mempelajari tafsir, berpikir, berdiskusi, berefleksi, memahami isi kandungan dan hikmahnya, mengimplementasikannya dalam kehidupan, serta menyebarkannya kembali ke orang-orang sekitar. Program ini didesain secara khusus dengan learning culture di dalamnya sehingga pembelajaran bisa dilakukan dengan interaktif, atraktif dan efektif. Peserta hanya terbatas 20-30 orang dengan rentang usia 17-27 tahun ${ }^{29}$ dan rata-rata diikuti oleh mahasiswa aktif maupun pasca kampus. Program Online Course Al-Qur'an menjadi salah satu program unggulan Guidelight selama satu tahun berdiri. ${ }^{30}$

Sistem pembelajaran yang dibentuk dalam program Online Course Al-Qur'an menyesuaikan dengan goals yang dituju, yakni agar para peserta bisa next level dalam interaksinya dengan Al-Qur'an. Safe'i Ridwan berharap bahwa hikmah-hikmah yang didapatkan dapat diimplementasikan dalam kehidupan. Dari goals itulah diturunkan ke kurikulumnya. Program Harvard Business Online yang diakses melalui website dan unggahan dari akun Instagram @quranreview juga menjadi benchmark dalam mengemas sistem pembelajaran di program ini. ${ }^{31}$

Kurikulum yang disusun adalah hasil diskusi antara Safe'i Ridwan dengan Qurba. $\mathrm{id}^{32}$ yang mana hasil diskusi tersebut memunculkan 9 bahasan yang disepakati menjadi kurikulum pembelajaran, yaitu tentang surat yang dibahas, tafsir ayat, asbab an-nuzul ayat (jika ada), kisah terpilih, mufrodat, balaghah Al-Qur'an, ayat-ayat ahkam, hikmah/ fawaid, dan bentuk pengamalan ayat dalam konteks saat ini. Adapun 9 hal ini menjadi konsep dasar yang mana saat program berjalan akan dikembangkan oleh tim Content

${ }^{27}$ Ahmad Safe'i Ridwan, dkk., Indonesia Guidelight Project: A Beginning to Understand His Words, h. 3, tidak diterbitkan.

${ }^{28}$ Ahmad Safe'i Ridwan, dkk., Indonesia Guidelight Project: A Beginning to Understand His Words, h. 3, tidak diterbitkan.

${ }^{29}$ Rentang usia ini dipilih karena usia 17 tahun dianggap sebagai batas minimal taraf usia dewasa dan sudah mampu memahami konteks pembelajaran. Sedangkan usia 25-27 tahun karena tim yang mengelola program juga rentang usia ini, dengan begitu diharapkan lebih mudah dalam komunikasi dan penyatuan frekuensi.

${ }^{30}$ Ahmad Safe'i Ridwan, dkk., Indonesia Guidelight Project: A Beginning to Understand His Words, h. 3, tidak diterbitkan.

${ }^{31}$ Wawancara dengan Co-Founder Indonesia Guidelight Project, Nur Rizkya Hanifa pada hari Kamis, 22 Juli 2021, pukul 20.00 WIB.

${ }^{32}$ Qurba.id adalah platform yang diinisiasi oleh beberapa alumni dan Mahasiswa Universitas Indonesia dan LIPIA Jakarta.yang menyajikan bahan bacaan melelaui reminder harian di instagram seputar literasi Quran dan Bahasa Arab. (sumber: akun instagram@qurba.id) 
Development ${ }^{33}$ dan narasumber di Study Series serta Value and Learning Cultures ${ }^{34}$ yang Guidelight miliki sebagai pondasi untuk memaksimalkan kurikulum yang dibentuk. ${ }^{35}$

Syarat dan ketentuan peserta untuk program ini diantaranya adalah muslim usia 1727 tahun, bersedia berkomitmen mengikuti seluruh rangkaian sesuai timeline yang sudah ditentukan, mampu membaca Al-Qur'an dengan baik (dibuktikan dengan melampirkan rekaman bacaan Quran pada formulir pendaftatan), bersedia mengunduh aplikasi yang dibutuhkan (Instagram, WhatsApp, Google Meet) dan seterusnya. ${ }^{36}$

Per Juli 2021, program Online Course Al-Qur'an sudah memiliki 4 Batch (angkatan). Batch 1 membahas Surat Al-Kahfi, Batch 2 membahas Surat Yusuf, Batch 3 membahas Surat Yasin dan Batch 4 membahas Surat Luqman. Program ini mendapat sambutan hangat dan antusias dari para pemuda-pemudi muslim Indonesia. Informasi tentang program ini mereka dapatkan dari berbagai media. Mulai dari media sosial seperti Instagram dan YouTube, maupun dari teman mereka. ${ }^{37}$ Profesi yang melatarbelakangi para peserta juga beragam. Mulai dari Pelajar SMA, Mahasiswa Sarjana dan Pascasarjana, ASN, Freelancer, Pengusaha, Pengajar dan Karyawan Swasta. ${ }^{38}$

Apresiasi para peserta yang kini telah menjadi alumni dapat dilihat ketika mereka meresepsi program Online Course Al-Qur'an maupun komunitas Guidelight itu sendiri. Para peserta yang mengikuti program pada saat bulan Ramadhan seperti Muhamad Ariz Pratama, Ibrahim M. Akadji dan Ruri Alifia Ramadhani meresepsi program ini sebagai media untuk mengisi waktu agar lebih produktif di bulan Ramadhan. Ruri mengatakan bahwa ia ingin menjadikan Ramadhannya lebih baik dari tahun sebelumnya dengan mendekatkan diri kepada Allah dan Al-Qur'an. ${ }^{39}$

${ }^{33}$ Tim Content Development disebut juga tim material adalah divisi utama dalam program Online Course Al-Qur'an. Tugasnya antara lain berkoordinasi dengan narasumber/pengisi Study Series, membuat Reading Material (modul pembelajaran), membuat penugasan (Smart Quiz dan pemantik Sharing Session), mengoreksi dan menilai seluruh tugas peserta serta membuat rapor peserta di akhir program.

${ }^{34}$ Untuk menjaga berjalannya program yang masih berbasis online agar tetap kondusif dan berjalan baik, maka Guidelight membawa nilai-nilai yang harus diterapkan oleh seluruh tim maupun peserta, yakni Ikhlas, Iqro, Think Critically, Be Proactive dan Engage. Lihat Ahmad Safe'i Ridwan, dkk., Buklet Registrasi Online Course Batch IV: Lights Your Ramadhan with Gems from Surah Luqman, h. 2, tidak diterbitkan.

${ }^{35}$ Wawancara dengan Founder Indonesia Guidelight Project, Ahmad Safe'i Ridwan pada hari Kamis, 22 Juli 2021, pukul 20.00 WIB.

${ }^{36}$ Ahmad Safe'i Ridwan, dkk., Buklet Registrasi Online Course Batch IV: Lights Your Ramadhan with Gems from Surah Luqman, h. 7-8, tidak diterbitkan.

37 Wawancara dengan 26 alumni program Online Course Al-Qur'an. Dilaksanakan melalui pengisian Google Form mulai hari Senin, 26 Juli 2021 hingga Kamis, 29 Juli 2021. Terdiri dari 6 orang alumni Batch 1, 7 orang alumni Batch 2, 3 orang alumni Batch 3, 9 orang alumni Batch 4 dan 1 orang yang mengikuti program sebanyak 2 kali, yakni Batch 3 dan 4 . Hasilnya, 14 orang mendapatkan informasi dari Instagram, 11 orang dari teman dan 1 orang dari YouTube.

${ }^{38}$ Terdiri dari 2 Pelajar SMA, 13 Mahasiswa, 4 Pengajar, 1 ASN, 2 Pengusaha, 2 Freelancer dan 2 Karyawan Swasta.

${ }^{39}$ Wawancara dengan Ibrahim M. Akadji, Muhamad Ariz Pratama dan Ruri Alifia Ramadhani pada hari Senin 26 Juli 2021 hingga Kamis, 29 Juli 2021. Ariz dan Ibrahim adalah alumni Batch 1 sedangkan Ruri adalah alumni Batch 4. Dimana Batch 1 dilaksanakan pada saat Ramadhan $1441 \mathrm{H}$, yakni bulan April-Mei 2020. Sedangkan Batch 4 dilaksanakan saat Ramadhan 1442 H, yakni bulan April-Mei 2021.

142 | Al-Fanar: Jurnal Ilmu Al-Qur'an dan Tafsir 
Sebagian peserta lainnya meresepsi program tersebut sebagai media untuk meningkatkan kualitas interaksi mereka dengan Al-Qur'an. Seperti Mufidah dan Ahmad Fauzy Habiby Prasetya yang ingin menambah hafalan Al-Qur'an melalui program ini. ${ }^{40}$ Sedangkan Hafshah Farah Fadhilah, Siti Uswatun Khasanah, Nadya Ahyani, Nurul Ain Saraswati, Althaf Abrar Tianto, Nur Muhammad Khanif, Vera Setianingsih, Firda Shabrina, Muhammad Ichsan Rahman, Ruliah Sari, Rayhana Yamini, Armita Dwi Fairuz, Putri Retno Pambayun dan Faris Abdurrahman meresepsi program ini sebagai media untuk lebih memahami Al-Qur'an secara komprehensif dengan mempelajari tafsir dan pesan yang dikandung dalam Al-Qur'an sesuai surat yang dipelajari sehingga bisa diimplementasikan dalam kehidupan. ${ }^{41}$

Batch 1 yang membahas Surat Al-Kahfi memiliki tema seputar penguatan akidah melalui kisah pemuda Al-Kahfi, kisah pemilik dua kebun, kisah Nabi Musa as. dan Nabi Khidir as, serta kisah tentang Dzulqarnain. Menurut Amna El Sayida, salah satu yang paling melekat yaitu kisah tentang Nabi Musa as. yang berguru kepada Nabi Khidir as. Berisi penjelasan tentang adab ketika mengambil ilmu dari seorang guru. Kisah ini secara keseluruhan terdapat dalam QS. Al-Kahfi ayat 60-82. Poin yang Amna dapatkan adalah hendaknya bersabar terhadap apa-apa yang belum diketahui oleh para penuntut ilmu. ${ }^{42}$ Sedangkan bagi Prasetyo Aji Laksono, pelajaran yang didapatkan ialah senantiasa mengintrospeksi diri di setiap peristiwa yang terjadi dan menghubungkannya dengan kejadian dari surat Al-Kahfi. Materi yang paling berkesan menurutnya yakni saat penjelasan tentang kisah pemuda yang ditidurkan oleh Allah selama ratusan tahun. ${ }^{43}$

Kisah yang dimaksud terdapat dalam QS. Al-Kahfi ayat 9-26. Sebagian ahli tafsir menyebutkan bahwa 7 pemuda itu merupakan orang Nasrani, namun menurut Ibn Katsir mereka ada sebelum Nabi Isa as. Para pemuda itu melarikan diri dari tekanan raja yang zalim demi menjaga akidah dan keyakinan mereka. Kisah ini memiliki pelajaran tentang teguhnya keimanan para pemuda yang rela meninggalkan harta mereka demi menjaga keyakinan dan akidah mereka yang sangat berharga dalam kehidupan. ${ }^{44}$

Batch 2 membahas Surat Yusuf, di mana surat ini mengisahkan tentang kehidupan Nabi Yusufas. Menurut Putri Retno Pambayun, banyak sekali pelajaran yang ia dapatkan. Mulai dari kondisi sosial, hubungan dalam keluarga, cara menyikapi momen hidup yang pahit maupun yang senang, dan juga cara cerdas dan bijak menyikapi masalah. Materi yang paling berkesan menurut Ayun adalah tentang reward \& punishment yang Nabi Yusuf as. terapkan dalam strategi beliau untuk bisa membuat saudara-saudaranya membawa Bunyamin ke Mesir. Materi ini berkesan bagi Ayun karena mengajarkan kecerdasan dan ketenangan dalam menghadapi masalah, bagaimana mengahadapi orang yang dahulu melukai dan cara memilih langkah penyelesaiannya. ${ }^{45}$

${ }^{40}$ Wawancara dengan Mufidah dan Ahmad Fauzy Habibiy Prasetya pada hari Senin, 26 Juli 2021 hingga Kamis, 29 Juli 2021.

${ }^{41}$ Wawancara dengan Hafshah Farah Fadhilah, Siti Uswatun Khasanah, Nadya Ahyani, Nurul Ain Saraswati, Althaf Abrar Tianto, Nur Muhammad Khanif, Vera Setianingsih, Firda Shabrina, Muhammad Ichsan Rahman, Ruliah Sari, Rayhana Yamini, Armita Dwi Fairuz, Putri Retno Pambayun dan Faris Abdurrahman pada hari Senin, 26 Juli 2021 hingga Kamis, 29 Juli 2021.

${ }^{42}$ Wawancara dengan Amna El Sayida pada hari Kamis, 29 Juli 2021 pukul 06.47 WIB.

${ }^{43}$ Wawancara dengan Prasetyo Aji Laksono pada hari Kamis, 29 Juli 2021 pukul 08.43 WIB.

${ }^{44}$ Ahsin Sakho Muhammad, Keberkahan Al-Qur'an: Memahami Tema-Tema Penting Kehidupan dalam Terang Kitab Suci, (Jakarta: PT. Qaf Media Kreativa, 2017), Cet. I, h. 270.

${ }^{45}$ Wawancara dengan Putri Retno Pambayun pada hari Senin, 26 Juli 2021 pukul 19.13 WIB. 
Indonesia Guidelight Project dan Tafsir Audiovisual: Tinjauan atas Metodologi Tafsir dan Kontribusinya di Masa Pandemi

Sedangkan menurut Ibrahim Hasan Ali, tadabbur kisah Nabi Yusuf as. yang membahas tentang etika berdoa kepada Allah menjadi kesan tersendiri. Di mana, do'a diawali dengan memuji Allah. Ibrahim mengungkapkan bahwa bagian kisah tersebut cukup membuatnya terhanyut dan mengintrospeksi diri karena selama ini do'a yang dipanjatkan terkadang belum diawali dengan menyebut kebaikan-Nya terlebih dulu. ${ }^{46}$

Batch 3 membahas Surat Yasin. Pokok pembahasan surat ini diantaranya adalah menanamkan serta meluruskan akidah yang berkaitan dengan keesaan Allah, risalah kenabian, kebenaran Al-Qur'an, dan kepastian adanya kiamat. Menurut Haekal Maulana, kisah seorang lelaki yang diabadikan dalam QS. Yasin ayat 20-27 menjadi materi yang berkesan. ${ }^{47}$ Menurut sebagian mufasir, lelaki tersebut bernama Habib AnNajjar yang lari tergesa-gesa menuju kaumnya untuk meminta agar mengikuti tiga utusan yang Allah kirimkan.

Habib An-Najjar berdakwah dan mengajak kaumnya dengan penuh cinta serta kelembutan agar beriman kepada Allah. Namun, ajakan tersebut dibalas dengan pembunuhan yang dilakukan oleh kaumnya. Pelajaran dari kisah ini adalah ketulusan dalam berdakwah tidak cukup sekadar karena Allah saja tetapi berdakwah karena kita mencintai orang-orang yang kita dakwahi. Menasihati bukan karena ingin menghakimi dan menunjukkan kesalahan mereka, melainkan karena kita betul-betul mencintai mereka serta merasa sedih melihat mereka jauh dari Allah. ${ }^{48}$

Batch 4 membahas tentang Surat Luqman. Pokok pembahasannya adalah seputar keistimewaan Al-Qur'an, ajakan kepada ketauhidan, kisah tentang Luqman al-Hakim dengan berbagai hikmahnya, dan lain-lain. Materi yang paling berkesan menurut Mufidah, Nur Muhammad Khanif, Vera Setianingsih dan Ruliah Sari adalah tentang Birr al-Walidain. ${ }^{49}$ Vera mengatakan bahwa penjelasan QS. Luqman ayat 15 tentang bagaimana memperlakukan kedua orang tua di dunia dengan perlakukan yang baik adalah yang paling berkesan karena sangat berkaitan erat dengan ujian kehidupan yang sedang Vera alami. ${ }^{50}$

Program Online Course Al-Qur'an juga diresepsi sebagai media belajar AlQur'an yang komprehensif. Mengingat bahwa kegiatan yang wajib untuk diikuti oleh para peserta cukup banyak dan padat. Terdiri dari Memorizing ${ }^{51}$, Study Series ${ }^{52}$,

${ }^{46}$ Wawancara dengan Ibrahim Hasan Ali pada hari Senin, 26 Juli 2021 pukul 19.01 WIB.

${ }^{47}$ Wawancara dengan Haekal Maulana pada hari Senin, 26 Juli 2021 pukul 16.43 WIB.

${ }^{48}$ Tim Content Development Guidelight, Reading Materials Guidelight Batch III Pekan 3: Ayat 22-32, h. 3-5, tidak diterbitkan.

${ }^{49}$ Wawancara dengan Mufidah, Nur Muhammad Khanif, Vera Setianingsih dan Ruliah Sari pada hari Senin, 26 Juli 2021 hingga Kamis, 29 Juli 2021.

${ }^{50}$ Wawancara dengan Vera Setianingsih pada hari Senin, 26 Juli 2021 pukul 17.45 WIB.

51 Para \#LightSeekers akan diajak untuk sama-sama fokus menghafal dan menguasai satu surah dengan menggunakan seluruh indera yang dimilikinya. Terdapat pula sesi mentoring $2 \mathrm{x} /$ pekan untuk berprogres, setoran hafalan, menjaga semangat menghafal serta mengoreksi bacaannya. \#LightSeekers juga akan dibantu oleh mentor untuk menemukan cara terbaiknya dalam menghafal Alquran.

${ }^{52}$ Kajian tafsir $1 \mathrm{kali} /$ pekan, setiap hari Senin. Melalui program ini para \#LightSeekers akan fokus mempelajari surah yang dibahas secara lebih mendalam bersama pemateri yang ahli di bidangnya. Mulai dari memahami tafsirnya, kosakatanya, sebab-sebab diturunkannya, hikmahnya, sampai bagaimana implementasinya dalam kehidupan sehari-hari.

144 | Al-Fanar: Jurnal Ilmu Al-Qur'an dan Tafsir 
Smart Quiz ${ }^{53}$, Sharing Session ${ }^{54}$, Monitoring dan Evaluasi (Monev) ${ }^{55}$, \#LightSeekers' Final Challenge ${ }^{56}$ dan Online Graduation ${ }^{57}$ Setiap agenda tersebut (kecuali Online Graduation) diadakan pada pukul 06.00 WIB. Hal ini dimaksudkan untuk membangun kebiasaan baik yang membuat panitia maupun peserta selalu terjaga dari tidur di pagi hari dan menjaga keberkahan waktu subuh. ${ }^{58}$

Dari rangkaian kegiatan tersebut, ada momen tertentu yang membuat para peserta excited selama mengikuti program. Bagi sebagian besar peserta, kegiatan Study Series menjadi momen yang dinanti-nanti. Menurut Ibrahim M. Akadji, penjelasan tafsir dari narasumber membuatnya takjub dengan hikmah dibalik setiap ayat. ${ }^{59}$ Bagi Ibrahim Hasan Ali, momen Sharing Session adalah yang berkesan karena agendanya yang cukup santai dengan pembahasan yang seru dan mentor yang sering membagikan insight yang luar biasa ${ }^{60}$ Sedangkan bagi Siti Uswatun Hasanah, Smart Quiz membuatnya excited dan juga hectic. Menurutnya, pengerjaan tugas seakan dikejar waktu. Karena mengingat saat itu ia juga memiliki target pribadi di bulan Ramadhan. ${ }^{61}$ Dan bagi sebagian yang lain, kegiatan seperti Monev dan menyetorkan hafalan juga memiliki kesan tersendiri.

Sebagian besar peserta menilai sistem pembelajaran secara keseluruhan sudah baik, menarik, efektif, interaktif, dan sistematis. Menurut Putri Retno Pambayun, alur pembelajarannya lengkap karena diberikan fasilitas mulai dari persiapan, asupan kognitif, sampai isu pemantik untuk diamalkan dalam kehidupan sehari-hari, baik dalam program pekanan maupun proyek akhir peserta. Support dari panitia baik secara

53 Penugasan 2 kali/pekan. Para \#LightSeekers akan mendapatkan serangkaian pertanyaan singkat sebelum (Pre-Quiz) dan sesudah study series. Kuis ini akan membantu para \#LightSeekers untuk mengevaluasi hafalan dan pemahamannya dari Reading Material serta materi yang diberikan oleh ustadz pada agenda Study Series di setiap pekan.

${ }^{54}$ Agenda 1 kali/pekan setiap hari Jum'at. Di sini \#LightSeekers akan mendiskusikan materi yang sudah dipelajari dan dipahami sebelumnya. Para \#LightSeekers didorong untuk melatih kemampuan public speaking dan menjelaskan kembali materi dengan bahasa yang sederhana dan mudah untuk dipahami. Sharing session ini dilaksanakan bersama kelompok dan para mentor terbaik kita. Sesi ini juga menjadi sarana trigger bagi \#LightSeekers untuk berpikir kritis dan mentransformasi ilmu menjadi amal.

${ }^{55}$ Agenda 1 kali/pekan, setiap hari Sabtu. Progres dari setiap target akan dimonitor dan dievaluasi setiap pekannya. Para \#LightSeekers akan mendapatkan penguatan guna menambah semangat dalam menghafal dan agar dapat lebih engage dengan program. \#LightSeekers juga dapat memberikan masukan atau feedback untuk pengembangan program kedepannya.

56 Tantangan akhir ini merupakan bentuk implementasi dari salah satu Values and Learning Cultures Guidelight yaitu Be Proactive. Para \#LightSeekers didorong untuk membuat project baik secara individu atau kelompok dalam rangka memastikan bahwa ilmu dan benefit yang telah diterima tidak akan berhenti sampai dirinya sendiri saja, melainkan orang-orang disekitarnya juga harus dapat merasakan manfaatnya. Per Juli 2021, sudah ada dua buku antologi yang merupakan produk dari hasil pembelajaran \#Lightseekers Batch 2 dan Batch 4. Masing-masing berjudul "Pearls from Surah Yusuf” dan "The Wisdom Ocean of Surah Luqman”.

${ }^{57}$ Online Graduation sebagai agenda penutup dan pemberian apresiasi kepada para \#LightSeekers yang telah mengikuti seluruh rangkaian program.

${ }^{58}$ Ahmad Safe'i Ridwan, dkk., Buklet Registrasi Online Course Batch IV: Lights Your Ramadhan with Gems from Surah Luqman, h. 3-4, tidak diterbitkan.

${ }^{59}$ Wawancara dengan Ibrahim M. Akadji pada hari Senin, 26 Juli 2021 pukul 16.55 WIB.

${ }^{60}$ Wawancara dengan Ibrahim Hasan Ali pada hari Senin, 26 Juli 2021 pukul 19.01 WIB.

${ }^{61}$ Wawancara dengan Siti Uswatun Hasanah pada hari Selasa, 27 Juli 2021 pukul 11.23 WIB. 
verbal via grup yang membentuk lingkup belajar yang kondusif dan rapor peserta yang mencakup nilai kognitif dan motivasi juga membuat sistem pembelajaran secara keseluruhan sudah sangat baik. ${ }^{62}$ Begitu pun menurut Mufidah, menurutnya sudah sangat menarik dan inovatif karena tidak hanya menghafal surat namun disertai pembelajaran tafsir dan tadabbur ke kehidupan sehari-hari sehingga ayat yang dihafal juga dapat diaplikasikan di kehidupan. ${ }^{63}$

Sistem pembelajaran tersebut juga dinilai menyenangkan. Seperti yang dirasakan oleh Prasetyo Aji Laksono. Ia menilai bahwa kondisi yang dibangun tidak hanya satu arah melainkan dua arah dalam bentuk diskusi dan pemberian feedback. Ruliah Sari dan Nur Muhammad Khanif juga memiliki kesan terhadap superteam Guidelight. Ruliah mengatakan bahwa superteam Guidelight selalu ramah namun tetap tegas. Khanif juga mengapresiasi superteam Guidelight yang sangat antusias di setiap sesi. Hal serupa juga disampaikan oleh Rosyidatun Sholihah, menurutnya support system yang terbentuk luar biasa bagus dan lengkap. Semua unsur dalam pendidikan masuk ke sistem pembelajaran Guidelight dengan sistem monitoring yang aktif dan bagus. ${ }^{64}$

Komunitas ini juga diresepsi oleh para peserta sebagai media untuk mendapatkan relasi baru, lingkungan positif dan teman-teman dari seluruh Indonesia yang memiliki semangat untuk sama-sama mempelajari Al-Qur'an. Putri Retno Pambayun mengatakan bahwa sangat bersyukur dan senang sekali karena mendapatkan pencerahan dan temanteman yang selalu mengajak kepada kebaikan. Rosyidatun Sholihah juga mengatakan bahwa komunitas ini adalah wadah untuk mencari ridho Allah melalui menghafal, mentadabburi dan mengamalkan isi kandungan Al Quran bersama teman-teman dalam satu iman dan ikatan misi yang sama. Hal serupa juga diungkapkan sebagian besar peserta lainnya. ${ }^{65}$

Para peserta juga meresepsi program ini sebagai sarana untuk menempa diri dan membentuk kebiasaan baik. Hal ini dapat dilihat dari dampak dan perubahan positif yang dirasakan para peserta. Vera Setianingsih yang merupakan peserta Batch 4 mengatakan bahwa dengan mempelajari surat Luqman, Vera mampu berproses untuk memperbaiki diri dan menerima ketentuan dari Allah. Ibrahim M. Akadji merasakan ketika tilawah surat Al-Kahfi menjadi lebih bermakna karena sedikit banyak sudah mengetahui makna dan hikmah dibalik surat tersebut. Sementara Armita Dwi Fairuz merasakan semakin appreciate terhadap Al-Qur'an. Armita mengatakan bahwa selalu berusaha untuk tadabbur dan mencari hikmah yang bisa diambil dari setiap ayat yang dibaca. ${ }^{66}$

Sebagian besar peserta juga merasakan dampak positif berupa semangat untuk terus menghafal dan mengkaji Al-Qur'an meskipun sudah menyelesaikan program. Selain itu, dampak positif lainnya adalah menjadi lebih produktif dan semangat untuk menjaga keberkahan waktu subuh. Seperti yang dirasakan oleh Siti Uswatun Hasanah,

${ }^{62}$ Wawancara dengan Putri Retno Pambayun pada hari Senin, 26 Juli 2021 pukul 19.13 WIB.

${ }^{63}$ Wawancara dengan Mufidah pada hari Senin, 26 Juli 2021 pukul 21.25 WIB.

${ }^{64}$ Wawancara dengan Prasetyo Aji Laksono, Ruliah Sari, Nur Muhammad Khanif dan Rosyidatun Sholihah pada hari Senin, 26 Juli 2021 hingga Kamis, 29 Juli 2021.

${ }^{65}$ Wawancara dengan Putri Retno Pambayun dan Rosyidatun Sholihah pada hari Senin, 26 Juli 2021.

${ }^{66}$ Wawancara dengan Vera Setianingsih, Ibrahim M. Akadji dan Armita Dwi Fairuz pada hari Senin, 26 Juli 2021 hingga Kamis, 29 Juli 2021.

146 | Al-Fanar: Jurnal Ilmu Al-Qur'an dan Tafsir 
Nur Muhammad Khanif, Ibrahim M. Akadji, Amna El Sayida, dan Mufidah. ${ }^{67}$

Komunitas Indonesia Guidelight Project juga diresepsi sebagai media dakwah Al-Qur'an yang menarik dan interaktif. Hal ini dapat dilihat dari kesan dan harapan para peserta terhadap Guidelight. Menurut Ibrahim M. Akadji, Guidelight merupakan media dakwah yang menjadi jawaban dari keresahan banyak orang terhadap pemuda muslim yang terlihat banyak meninggalkan Al-Qur'an. Menurutnya, Guidelight mampu merubah anggapan sebagian pemuda Indonesia tentang pembelajaran AlQur'an yang sulit, monoton dan membosankan menjadi menarik dan menyenangkan sehingga mereka tergerak untuk menelaah kembali kitab suci mereka. Menurut Vera Setianingsih, Guidelight telah membuka kesempatan bagi masyarakat umum untuk mendalami Al-Qur'an dengan latar belakang yang berbeda. Vera mengatakan,

“...Allah tunjukan kesempurnaan-Nya lewat detail ayat yang tak ada salah, kebenaran berbagai sudut pandang \& keindahan aturan-Nya dan itu yang aku rasakan mengikuti Guidelight batch 4."

Selain itu, Putri Retno Pambayun juga berharap agar kedepannya Guidelight bisa lebih mengoptimalkan semua media online dan mencoba masuk ke ranah sosial dalam berdakwah. Muhammad Husain juga berharap, Guidelight mampu menjadi pelopor lembaga pembelajaran Al-Qur'an yang terpercaya di Indonesia demi muslim Indonesia yang lebih sadar Al-Qur'an dan memperluas kolaborasi serta manfaat hingga lingkup internasional. Sebagian besar harapan para peserta adalah agar Guidelight terus istiqomah membumikan Al-Qur'an dan selalu Allah beri keridhoan, kekuatan serta kelancaran untuk bisa melebarkan sayap dan meluaskan manfaat. ${ }^{68}$

Selain resepsi yang telah penulis paparkan, para peserta juga mengalami beberapa kendala selama mengikuti program Online Course Al-Qur'an. Pertama, kendala dalam memahami materi yang berkaitan dengan bahasa Arab dan balaghah Al-Qur'an. Karena sebagian besar peserta belum memiliki pengetahuan dasar bahasa Arab maupun ilmu pengetahuan agama yang memadai seperti yang dipelajari oleh para santri di pondok pesantren.

Kedua, kendala internal seperti menahan rasa kantuk di pagi hari, kedisiplinan diri, semangat yang tidak stabil, kurang fokus ataupun sakit. Seperti yang dialami oleh Ibrahim M. Akadji, Siti Uswatun Hasanah dan Nurul Ain Saraswati yang sempat sakit saat menjalani program. Ibrahim mengatakan bahwa kondisi tubuhnya yang kadang kurang fit membuatnya tidak bisa menerima materi dengan baik. Adapun memanajemen kedisiplinan diri dan konsistensi juga menjadi kendala internal bagi Mufidah, Muhammad Husain, Armita Dwi Fairuz dan Faris Abdurrahman. ${ }^{69}$

Ketiga, kendala eksternal seperti jaringan dan kuota data internet yang dialami sebagian besar peserta. Muhammad Ichsan Rahman mengatakan bahwa sinyal yang terputus secara mendadak membuat penjelasan juga terputus. Seperti Prasetyo Aji Laksono yang juga sering mengalami masalah sinyal dikarenakan banyak yang memakai

\footnotetext{
${ }^{67}$ Wawancara dengan Siti Uswatun Hasanah, Nur Muhammad Khanif, Ibrahim M. Akadji, Amna El Sayida, dan Mufidah pada hari Senin, 26 Juli 2021 hingga Kamis, 29 Juli 2021.

68 Wawancara dengan Ibrahim M. Akadji, Vera Setianingsih, Putri Retno Pambayun dan Muhammad Husain pada Hari Senin, 26 Juli 2021 hingga Kamis, 29 Juli 2021.

${ }^{69}$ Wawancara dengan Ibrahim M. Akadji, Siti Uswatun Hasanah, Nurul Ain Saraswati, Mufidah, Muhammad Husain, Armita Dwi Fairuz dan Faris Abdurrahman pada Hari Senin, 26 Juli 2021 hingga Kamis, 29 Juli 2021.
} 
wifi oleh anggota keluarganya secara bersamaan. Selain itu, keperluan mendadak, jam kampus dan agenda lain di luar Guidelight juga menjadi faktor kendala eksternal. Seperti yang dialami oleh Ruri Alifia Ramadhani, Rayhana Yamini dan Amna El Sayida. Ruri adalah seorang ASN yang kini bertugas di Kabupaten Kepulauan Anambas, Provinsi Kepulauan Riau. Ia merasa terkendala untuk mencocokkan waktu karena ada beberapa kegiatan program yang berlangsung beririsan dengan jam kerja. Sedangkan Rayhana merupakan Mahasiswa Klinik dimana saat akhir periode Batch 2 sedang menjalani stase mayor di kepaniteraan klinik. Sedangkan Amna, cukup merasa dikejar waktu karena durasi Study Series beririsan dengan kelas jam pertama kuliah. ${ }^{70}$

Selain tiga kendala tersebut, para peserta juga memiliki saran dan evaluasi bagi Guidelight agar lebih baik kedepannya. Pertama, perihal Study Series. Hafshah Farah Fadhilah menilai bahwa Study Series membutuhkan sesi yang lebih banyak namun dengan durasi yang lebih singkat. Sedangkan menurut Ibrahim M. Akadji yang perlu ditingkatkan adalah mengefisienkan penyampaian materi yang cukup banyak dengan dibuat lebih ringkas dan mudah dipahami karena adanya keterbatasan waktu. ${ }^{71}$

Kedua, perihal penugasan. Menurut Amna El Sayida, Prasetyo Aji Laksono, Vera Setianingsih, Nadya Ahyani, Muhammad Husain, Ruri Alifia Ramadhani, Ibrahim Hasan Ali dan Putri Retno Pambayun menilai bahwa teknis penugasan perlu dilakukan inovasi terkait konten dan jenis penugasan agar lebih variatif dan berdampak jelas dari sisi kebermanfaatannya. Menurut Ruri, teknis penugasan seharusnya bisa lebih menjangkau dalam lingkup kecil, sehingga secara kolektif tiap-tiap kelompok mentoring memiliki laporan penugasan. ${ }^{72}$

Ketiga, evaluasi untuk sesi Monev (Monitoring dan Evaluasi). Menurut Firda Shabrina, evaluasi pekanan tidak hanya mendeskripsikan evaluasi peserta tetapi Firda berharap agar diberikan juga solusi di setiap poin evaluasi peserta. Sedangkan menurut Ruliah Sari, panitia diharapkan lebih maksimal dalam mengumpulkan poin evaluasi peserta. Ruliah mengatakan apabila hal tersebut sudah maksimal, sistem yang sudah baik akan lebih berdampak lagi kebaikannya bagi peserta maupun program. ${ }^{73}$

\section{TAFSIR AUDIOVISUAL GUIDELIGHT: SEBUAH PENCARIAN METODOLOGIS}

Sebagaimana penafsiran yang terekam dalam literatur-literatur kitab tafsir, dengan keragaman penyajiannya tentunya, maka hal yang sama juga didapati dalam tafsir audiovisual. Tafsir audiovisual muncul dengan beragam variasi dan bentuk yang cukup banyak. Klasifikasi ini didasarkan pada komponen tafsir audiovisual meliputi metode penyajian yang disuguhkan, pendekatan tafsir yang digunakan, sumber penafsiran yang dipakai, referensi yang dijadikan sebagai rujukan dalam menafsirkan dan kecenderungan dalam bentuk kajian tafsirnya.

${ }^{70}$ Wawancara dengan Muhammad Ichsan Rahman, Prasetyo Aji Laksono, Ruri Alifia Ramadhani, Rayhana Yamini dan Amna El Sayida pada hari Senin, 26 Juli 2021 hingga Kamis, 29 Juli 2021.

${ }^{71}$ Wawancara Hafshah Farah Fadhilah dan Ibrahim M. Akadji pada hari Senin, 26 Juli 2021 hingga Kamis, 29 Juli 2021.

${ }^{72}$ Wawancara dengan Amna El Sayida, Prasetyo Aji Laksono, Vera Setianingsih, Nadya Ahyani, Muhammad Husain, Ruri Alifia Ramadhani, Ibrahim Hasan Ali dan Putri Retno Pambayun pada hari Senin, 26 Juli 2021 hingga Kamis, 29 Juli 2021.

${ }^{73}$ Wawancara dengan Firda Shabrina dan Ruliah Sari pada hari Senin, 26 Juli 2021 hingga Kamis, 29 Juli 2021.

148 | Al-Fanar: Jurnal Ilmu Al-Qur'an dan Tafsir 
Berikut penulis klasifikasi komponen tafsir yang disajikan oleh Indonesia Guidelight Project di Channel YouTube Guidelight.

\section{Metode Penyajian}

Metode penyajian tafsir yang dimaksud dalam kajian ini adalah cara atau bentuk penyajian mufasir, yang dalam hal ini para narasumber Guidelight dalam menafsirkan Al-Qur'an. Tidak jauh berbeda dengan metode penafsiran yang ada dalam kitabkitab tafsir, tafsir audiovisual Guidelight setidaknya memiliki tiga bentuk metode penyajian tafsir.

Pertama, Ijmalī (global). Bentuk tafsir Ijmalī merupakan model penafsiran dengan uraian yang singkat dan sederhana tanpa menjelaskan secara mendetail asbāb an-nuzūl, makna mufradāt dan lain sebagainya. Tafsir secara ijmalì didapati dalam program Guidelight yakni Quranic Webinar/Talkshow yang memang diperuntukkan bagi masyarakat secara umum. Inilah yang mungkin menjadi alasan narasumber menggunakan model penyajian ijmalī dalam menafsirkan Al-Qur'an agar bisa dipahami dengan mudah oleh audiens.

Kedua, tahlilī (rinci). Berbeda dengan penafsiran secara global, metode tahlilī adalah metode tafsir yang bermaksud menafsirkan ayat-ayat Al-Qur'an dari segala aspeknya, mulai dari menjelaskan mufaradāt (kosa kata) ayat, munāsabah (hubungan) antar ayat, sebab turun ayat, makna ayat secara global, tinjauan hukum yang terkandung dan tambahan penjelasan tentang qira'at, i'rab dan keistimewaan susunan kata-kata pada ayat-ayat yang ditafsirkan serta diperkaya dengan pendapat imam mazhab dan lain sebagainya. ${ }^{74}$

Jika melihat dari bentuk tafsir audiovisual Guidelight, penafsiran dengan menggunakan metode tahlilī terlihat pada program Online Course Al-Qur'an dan Free Online Course Tafsir Al-Qur'an Surat Pendek. Sang mufasir yang dalam hal ini adalah narasumber, berusaha menjelaskan ayat Al-Qur'an mulai dari makna kosa kata. Misalnya saja ketika Fahmi Aziz ${ }^{75}$ menafsirkan surat al-'Alaq, beliau menjelaskan makna huruf $b a$ ' pada potongan ayat 'bismi rabbika' bermakna al-isti' ānah (meminta tolong) dan ij'al hadza al-fi'il lillahi (jadikan bacaan ini semata-mata karena Allah). Selain memaknai kata, Fahmi Aziz juga menjelaskan asbāb an-nuzūl surah al-'Alaq mengenai kisah tahannuth Nabi Muhammad ketika di Gua Hira yang kemudian didatangi oleh Malaikat Jibril dengan membawa wahyu pertama.

Tidak luput dari pembahasan, aspek munāsabah juga disampaikan oleh mufasir pada tafsir audiovisualnya. Misalnya saja ketika Saihul Basyir ${ }^{76}$ menafsirkan surah an-Nās. Sebelum menafsirkan surah an-Nās, beliau menjelaskan keterkaitannya dengan surah al-Falaq, di mana surah al-Falaq menjelaskan permohonan perlindungan dari kejahatan yang muncul dari luar, sementara surah an-Nās berisikan permohonan perlindungan dari kejahatan yang timbul dalam diri manusia.

Ketiga, maudhu'̄̄ (tematik). Tafsir maudhu'̄̄ adalah menghimpun ayat-ayat Al-

\footnotetext{
${ }^{74}$ Rosalinda, “Tafsir Tahlili: Sebuah Metode Penafsiran Al-Qur'an”, dalam Jurnal Hikmah, Vol. 15, No. 2, 2019, h. 7.

${ }^{75}$ Narasumber Guidelight yang merupakan alumni Islamic University Madina pada tahun 2019.

${ }^{76}$ Narasumber Guidelight yang dalam judul kajiannya tercantum nama beliau dengan gelar Lc. Gelar Lc didapat dari Fakultas Syari'ah LIPIA Jakarta. Selain itu juga dalam judul kajiannya tertulis bahwa beliau hafizh Al-Qur'an 30 juz.
} 
Qur'an yang mempunyai maksud yang sama dalam arti sama-sama membicarakan satu topik masalah dan menyusunnya berdasar kronologi serta sebab turunnya ayatayat tersebut. Kemudian penafsir mulai memberikan keterangan dan penjelasan serta mengambil kesimpulan. ${ }^{77}$ Dalam tafsir audiovisual Guidelight terlihat ada dua bentuk model penafsiran maudhu' '̄, yaitu maudhu' $\bar{\imath}$ surat dan maudhu' $\bar{\imath}$ tema.

Adapun yang dimaksud maudhu' $\bar{\imath}$ surat adalah mengkaji sebuah surat dengan kajian universal (tidak parsial) yang di dalamnya dikemukakan misi awalnya, lalu misi utamanya; serta kaitan antara satu bagian surat dengan bagian lain, sehingga wajah surat itu mirip seperti bentuk yang sempurna dan saling melengkapi. ${ }^{78}$ Sebagai contoh tafsir audiovisual Guidelight yang menggunakan model penafsiran maudhu' $\bar{\imath}$ surat adalah penafsiran yang dilakukan oleh Amar Ar-Risalah. Beliau menafsirkan surah Luqmān secara keseluruhan dengan diberi tema "Shapping Quran Civilization: Starting from Home" atau membentuk peradaban Al-Qur'an dengan memulai dari rumah. Dalam mengawali penafsiran, beliau menjelaskan bahwa surah Luqmān merupakan surah makiyyah yang turun beberapa kali. Isi kandungan surah ini pada bagian pertama tentang hakikat Quran, pembagian jenis manusia, kekuasaan Allah kepada langit dan bumi sebagai tantangan kepada sosok tuhan yang disembah oleh orang kafir. Selanjutnya bagian kedua berisikan kisah Luqmān dan anaknya serta hikmah Luqmān. Yang menarik di sini narasumber berkompeten menggali kandungan surah dengan sangat apik dan mengaitkan dalam kehidupan sehari-hari, khususnya dalam pembahasan sesuai dengan tema surah.

Sementara untuk maudhu' $\bar{\imath}$ tema adalah mengumpulkan beberapa ayat dari banyak surat yang sama-sama membicarakan masalah tertentu. Kemudian ayat-ayat itu dirangkai sedemikan rupa pada satu tema pokok bahasan dan selanjutnya ditafsirkan secara maudhu' ${ }^{79}{ }^{79}$ Sebagai contoh tafsir audiovisual Guidelight yang menggunakan model penafsiran maudhu' $\bar{\imath}$ tema adalah penafsiran Aa Gym dalam Quranic Webinar dengan tema "Lighten Your Heart: Agar Hati selalu Tenang”. Dalam penafsirannya, Aa Gym mampu menyampaikan materi dengan sangat lugas dan baik dengan mengaitkan pada ayat-ayat dan hadis-hadis yang sesuai dengan tema. Hanya saja, secara metodologis penafsiran maudhu' $\mathrm{l}$ tema Aa Gym belum memenuhi. Hal ini terlihat bagaimana Aa Gym tidak mengumpulkan ayat-ayat secara teratur menurut kronologi masa turunnya, serta latar belakang turunnya ayat. Selain itu juga beliau tidak menganalisa beberapa ayat dan mengompromikan ayat yang 'am dan khas, mutlak dan muqayyad, mensinkronkan ayat-ayat yang lahirnya tampak kontradiktif dan lain sebagainya.

\section{Pendekatan Tafsir}

Berbicara mengenai pendekatan tafsir, setidaknya ada dua bentuk pendekatan tafsir yang biasa digunakan oleh para mufasir, yaitu pendekatan tekstual dan pendekatan kontekstual.

Pertama, pendekatan tekstual. Pendekatan tekstual dalam studi tafsir merupakan suatu usaha dalam memahami makna tekstual dari ayat-ayat Al-Qur'an. Pada

${ }^{77}$ Abd. Al-Hayyi al-Farmawi, Al-Bidāyah fì at-Tafsīr al-Mauḍu '̄̄, terj. Suryan A. Jamrah, Metode Tafsir al-Maudhu'i (Jakarta PT. Raja Grafindo Persada, 1994), h. 2.

${ }^{78}$ Makhfud, "Urgensi Tafsir Maudhu'i (Kajian Metodologis)", dalam Tribakti: Jurnal Pemikiran Islam, Vol. 27, No. 1. 2016, h. 15.

${ }^{79}$ Muslimin, “Kontribusi Tafsir Maudhu'i dalam Memahami Al-Qur'an”, dalam Tribakti: Jurnal Pemikiran Islam, Vol. 30, No. 1, 2019, h. 79.

150 | Al-Fanar: Jurnal Ilmu Al-Qur'an dan Tafsir 
pendekatan tekstual, praktik tafsir lebih berorientasi pada teks dalam dirinya ${ }^{80}$ Artinya pendekatan tekstual mendasarkan penafsiran hanya pada teks dan juga tradisi zaman Nabi Muhammad saw. serta banyak menggunakan kajian bahasa secara ketat.

Jika melihat dari penafsiran yang dilakukan oleh para mufasir Guidelight di beberapa video YouTubenya, hampir sebagaian besar penafsiran cenderung pada pendekatan tekstual. Sebagai contoh, ketika menafsirkan ayat pertama surat al-'Alaq, di mana pada penggalan kata iqra' hanya dipahami dengan membaca Al-Qur'an. Contoh lain juga didapati ketika menafsirkan surah an-Nās pada penggalan kata shudūr (dada). Menurutnya, penggunaan kata shudūr tidak dengan kata qulüb (hati) dalam ayat tersebut, karena bisikan setan hanya sampai pada dada, bukan hati. Hanya Allah yang sampai pada hati manusia. Selain itu, bentuk penafsiran dengan pendekatan tekstual lainnya dilihat ketika narasumber mencoba menjelaskan dari aspek gramatikalnya. Misalnya saja ketika Fahmi Aziz menjelaskan kata bismi rabbika pada surat al-'Alaq, beliau menjelaskan bahwa kedudukannya menjadi $h \bar{a} l$ (keadaan) dan lain sebagainya.

Kedua, pendekatan kontekstual. Pendekatan kontekstual yang dimaksud disini adalah pendekatan yang mencoba menafsirkan Al-Qur'an berdasarkan pertimbangan analisis bahasa, latar belakang sejarah, sosiologi, dan antropologi yang berlaku dalam kehidupan masyarakat Arab selama proses wahyu Al-Qur'an berlangsung. Setelah itu ditarik ke dalam konteks penafsir di mana ia hidup dan berada, dengan pengalaman sejarah, sosial, dan budayanya sendiri. ${ }^{81}$

Jika melihat dari penafsiran yang dilakukan oleh para mufasir Guidelight, secara metodologis hampir sebagian besar penafsiran belum memenuhi standar tafsir kontekstual. Memang, sang mufasir setelah melakukan penafsiran atas ayat yang dikaji selalu menyampaikan bagaimana bentuk pengamalan ayat dalam konteks saat ini. Misalnya saja dalam menafsirkan kata waswas dengan istilah insecure. Artinya sang mufasir mencoba mencari istilah atau contoh yang nyata dalam konteks saat ini ketika menggali makna kandungan Al-Qur'an. Hanya saja itu belum cukup dikatakan tafsir kontekstual.

\section{Sumber Penafsiran}

Berbicara mengenai sumber penafsiran, setidaknya ada dua sumber penafsiran yang dipakai oleh para mufasir Guidelight, yaitu tafsīr bi al-mathūr dan tafsīr bi al-ra'yz.

Pertama, tafsīr bi al-mathūr. Tafsīr bi al-mathūr yang dimaksud di sini adalah upaya menafsirkan ayat Al-Qur'an dengan ayat Al-Qur'an, ayat Al-Qur'an dengan Sunnah Rasulullah saw, ayat Al-Qur'an dengan perkataan Sahabat, dan ayat Al-Qur'an dengan perkataan Tabi'in. Hampir setiap kajian tafsir audiovisual yang dilakukan oleh Guidelight selalu bersumberkan pada bi al-mathūr. Sebagai contoh ketika para mufasir mengutip beberapa hadis, misalnya saja hadis tentang keutamaan membaca surah almu'awwidzatain sebelum menafsirkan surah an-nās, hadis qudsi tentang Allah sesuai dengan prasangka hamba-Nya ketika menjelaskan konsep hati tenang dalam Al-Qur'an, hadis tentang Ihsan yakni beribadah kepada Allah seakan-akan engkau melihatnya, jika engkau tidak melihat-Nya, maka Dia melihat engkau dan masih banyak hadis lainnya.

Kedua, tafsīr bi al-ra'yī. Tafsīr bi al-ra'yī yang dimaksud adalah penafsiran yang

${ }^{80}$ M. Solahudin, "Pendekatan Tekstual dan Kontekstual dalam Penafsiran A1-Qur'an”, dalam Jurnal Al-Bayan, Vol. 1 No. 2, 2016, h. 116.

${ }^{81}$ M. Solahudin, “Pendekatan Tekstual dan Kontekstual dalam Penafsiran Al-Qur'an”, h. 118. 
dilakukan dengan metode ijtihad dan menggunakan akal atau logika yang benar dengan menggunakan pemikiran yang benar dan memenuhi syarat dalam penafsiran secara benar mengikuti aturan yang berlaku. ${ }^{82}$ Hampir setiap kajian tafsir audiovisual yang dilakukan oleh mufasir Guidelight selalu bersumberkan pada bi al-ra'yī yang benar. Misalnya saja ketika menafsirkan makna kata, mengungkap aspek keindahan susunan kalimat dalam Al-Qur'an, menganalisa hikmah yang terkandung dalam ayat yang dikaji dan masih banyak lainnya.

\section{Referensi/Rujukan Tafsir}

Secara umum, jika dilihat dari aspek referensi atau rujukan tafsir audiovisual Guidelight merujuk pada kitab-kitab tafsir yang mu'tabar. Hanya saja memang kitab tafsir yang banyak dirujuk didominasi oleh kitab-kitab tafsir klasik, seperti yang disampaikan oleh Amar Ar-Risalah bahwa rujukan yang digunakan adalah Tafsīr Al-Qurān al- 'Aż̄im karya 'Imād al-Dīn Abu al-Fida' Ismā'il Ibn 'Amr Ibn Kathīr al-Busrā al-Dimașqī. Selain itu, kitab tafsir Mafātiḥ al-Ghaib karya Abu Abdillāh Muḥammad bin Umar bin al-Husain bin al-Hasan bin Alī al-Taimi al-Bakri al-Ṭibristan̄̄, atau yang terkenal dengan nama Fakhr al-Dīn al-Rāzī juga menjadi rujukan tafsir audiovisual Guidelight dengan mufasir Saihul Basyir. Sementara untuk kitab-kitab tafsir era kontemporer, penulis belum mendapati tafsir audiovisual Guidelight merujuk pada kitab tersebut.

Secara historis, penafsiran terhadap Al-Qur'an pada prinsipnya mengalami perkembangan yang sangat signifikan. Epistemologi penafsiran Al-Qur'an pada masa awal (klasik) hanya mengedepankan validitas tafsir pada aspek naql (riwayat) ketimbang aql (ra'yu). Itulah mengapa Hasan Hanafi menyampaikan bahwa tafsir klasik lebih banyak menyediakan wawasan tentang konteks sosial, sejarah, dan bahasa pada masanya daripada tentang Al-Qur'an itu sendiri. ${ }^{83}$

Berbeda dengan tafsir era kontemporer, di mana sang mufasir berusaha menggali makna Al-Qur'an tidak hanya dari aspek teksnya saja tetapi juga melihat aspek konteks. Pada prinsipnya rekonstruksi metodologis pada setiap masa perjalanan tafsir selalu dilingkupi oleh situasi dan kondisi yang berada di sekitar mufasir. Metode pun akan terus berkembang dengan berbedanya cara pandang satu mufasir dalam melihat kondisi dan situasi dengan mufasir lainnya.

\section{Genre/Kecenderungan Tafsir}

Beberapa genre yang muncul dalam tafsir audiovisual Guidelight dapat dilihat dari penafsiran narasumber di masing-masing video ketika menggali makna AlQur'an. Istilah genre yang digunakan dalam klasifikasi ini berbeda dengan istilah laun atau corak yang sering digunakan dalam klasifikasi kitab tafsir. Genre di sini lebih dimaksudkan sebagai berbagai kecondongan yang muncul dalam sebuah tafsir. Berbeda dengan tradisi kitab tafsir, klasifikasi genre ini tidak dapat dikaitkan dengan tokoh mufasirnya. Jika umumnya nuansa sebuah tafsir dalam kitab tafsir berkaitan erat dengan karakter mufasirnya, maka dalam tafsir audiovisual tidak demikian, sebab

${ }^{82}$ Muhammad Arsad Nasution, "Pendekatan dalam Tafsir (Tafsir bi Al-Matsur, Tafsir bi AlRa yi, Tafsir bi Al-Isyari)”, dalam Jurnal Yurisprudentia, Vol. 4, No. 2 2018, hlm. 155.

${ }^{83}$ Hassan Hanafi, "Method of Thematic Interpretation of the Al-Qur'an", dalam Stevan Wild (ed.), The Al-Qur'an as Text, (Leiden: E. J. Brill, 1996), hlm. 196. Lihat juga Budi Juliandi dan Saifuddin Herlambang, "Menggugat Tafsir Tekstual", dalam Jurnal At-Tibyan, Vol. I No.1, 2016, hlm. 51 .

152 | Al-Fanar: Jurnal Ilmu Al-Qur'an dan Tafsir 
seorang mufasir pada satu waktu bisa memiliki kecondongan fikih dalam tafsirnya dan politik pada waktu lain. Dalam tafsir audiovisual ini penulis menemukan setidaknya tiga genre tafsir.

Pertama, Linguistik. Genre ini banyak didapati dalam kajian tafsir audiovisual Guidelight, di mana sang mufasir menjelaskan ayat Al-Qur'an mulai dari aspek makna mufradāt, balāghah Al-Qurān, dan aspek gramatikalnya. Inilah yang kemudian makna yang muncul cenderung tekstual.

Kedua, Akhlak. Berbeda dengan tafsir yang lebih menekankan kajian linguistiknya, tafsir dengan kecenderungan akhlak beriorientasi pada ayat-ayat tentang akhlak dan menggunakan pendekatan ilmu akhlak. Sebagian besar surat yang dikaji dalam tafsir audiovisual Guidelight adalah ayat-ayat yang lebih condong untuk perbaikan akhlak, seperti surah Luqmān, Yusuf, Yāsin dan lain sebagainya.

Ketiga, Sosial. Kecenderungan sosial ini termasuk yang juga sering muncul dalam kajian tafsir audiovisual Guidelight. Secara umum mufasir akan mengaitkan penjelasan tafsir ini dengan kondisi sosial sebagai konteks tafsirnya. Salah satu contoh tafsir dengan genre sosial adalah ketika menafsirkan surat Luqmān. Luqmān mengajarkan hikmah diantaranya adalah perintah bersabar. Sang mufasir mengaitkan perintah bersabar ini dengan adanya tren investasi. Tren saham misalnya bisa dibeli dengan sangat murah. Hanya saja ada saham yang halal dan haram. Kehati-hatian menjadi kunci utama sebagai respon perintah sabar.

\section{PENUTUP}

Secara umum, munculnya Indonesia Guidelight Project menjadi satu diantara platform yang menyuguhkan kajian tafsir dengan bentuk wajah baru yakni tafsir audiovisual. Tafsir audiovisual Guidelight ini memberikan sumbangsih yang positif bagi masyarakat secara luas sehingga menambah pemahaman mereka terhadap kandungan Al-Qur'an dan menjadi pribadi yang lebih baik. Selain itu jika melihat dari aspek metodologis, tafsir audiovisual Guidelight secara substansi cukup informatif dengan menghadirkan narasumber yang memiliki kompetensi yang layak sebagai mufasir. Hanya saja untuk kebaikan kedepan bentuk penafsirannya lebih diperkaya dengan pendekatan-penedekatan kontekstual.

\section{DAFTAR PUSTAKA}

Al-Farmawi, Abd. Al-Hayyi. 1994. Al-Bidāyah fì at-Tafsīr al-Maudu'̄̄, terj. Suryan A. Jamrah, Metode Tafsir al-Maudhu'i. Jakarta PT. Raja Grafindo Persada.

Hairul, Moh. Azwar. 2019. "Tafsir Al-Qur'an di YouTube Telaah Penafsiran Nouman Ali Khan di Channel Bayyinah Institute dan Quran Weekly", dalam Al-Fanar: Jurnal Ilmu Al-Qur'an dan Tafsir, Vol. 2, No. 2.

Hamdan, Ali. 2019. "Dimensi Sosial dalam Wacana Tafsir Audiovisual: Studi atas Tafsir Ilmi, "Lebah Menurut al-Qur'an dan Sains," Lajnah Pentashihan Mushaf AlQur'an Kemenag RI di Youtube", dalam Religia: Jurnal Ilmu-Ilmu Keislaman, Vol. 22, No. 2.

Hanafi, Hassan. 1996. "Method of Thematic Interpretation of the AlQur'an", dalam Stevan Wild (ed.), The Al-Qur'an as Text, Leiden: E. J. Brill, 1996. 
Indonesia Guidelight Project dan Tafsir Audiovisual: Tinjauan atas Metodologi Tafsir dan Kontribusinya di Masa Pandemi

Jannah, Roudlotul. 2021. “Tafsir Al-Qur'an Media Sosial: Studi Model Tafsir pada Akun Instagram@Quranreview”, Skripsi, UIN Maulana Malik Ibrahim Malang, tidak diterbitkan.

Juliandi, Budi dan Saifuddin Herlambang. 2016. "Menggugat Tafsir Tekstual", dalam Jurnal At-Tibyan, Vol. I No.1.

Makhfud. 2016. "Urgensi Tafsir Maudhu'i (Kajian Metodologis)", dalam Tribakti: Jurnal Pemikiran Islam, Vol. 27, No. 1.

Muhammad, Ahsin Sakho. 2017. Keberkahan Al-Qur'an: Memahami Tema-Tema Penting Kehidupan dalam Terang Kitab Suci. Jakarta: PT. Qaf Media Kreativa.

Muslimin. 2019. “Kontribusi Tafsir Maudhu'i dalam Memahami Al-Qur'an”, dalam Tribakti: Jurnal Pemikiran Islam, Vol. 30, No. 1.

Nafiisatuzzahro'. 2018. “Transformasi Tafsir Al-Qur'an di Era Media Baru: Berbagai Bentuk Tafsir Al-Qur'an Audiovisual di YouTube", dalam Hermeneutik: Jurnal Ilmu Al Qur'an dan Tafsir, Vol. 12, No. 2.

Nasution, Muhammad Arsad. 2018. "Pendekatan dalam Tafsir (Tafsir bi Al-Matsur, Tafsir bi Al-Ra yi, Tafsir bi Al-Isyari)”, dalam Jurnal Yurisprudentia, Vol. 4, No. 22018.

Ridwan, Ahmad Safe'i, dkk. Indonesia Guidelight Project: A Beginning to Understand His Words, tidak diterbitkan.

Buklet Registrasi Online Course Batch IV: Lights Your Ramadhan with Gems from Surah Luqman, tidak diterbitkan.

Rosalinda. 2019. “Tafsir Tahlili: Sebuah Metode Penafsiran Al-Qur'an”, dalam Jurnal Hikmah, Vol. 15, No. 2.

Sauma, Moh Syahri. 2020. "Ayat-Ayat Audiovisual dalam Perspektif Dakwah Virtual (Kajian Tafsir Dakwah)”, Jurnal An-Nida', Vol. 8, No. 2.

Solahudin, M. 2016. "Pendekatan Tekstual dan Kontekstual dalam Penafsiran Al-Qur'an", dalam Jurnal Al-Bayan, Vol. 1 No. 2

Stephanie, Conney. "Pandemi Covid-19, Pendapatan Zoom Naik Hampir 4 Kali Lipat", dalam Kompas.com, pada tanggal 1 Desember 2020, https://tekno.kompas.com/ $\mathrm{read} / 2020 / 12 / 01 / 18120027 /$ pandemi-covid-19-pendapatan-zoom-naik-hampir-4kali-lipat dan diakses pada 03 Agustus 2021.

Tim Content Development Guidelight, Reading Materials Guidelight Batch III Pekan 3: Ayat 22-32, tidak diterbitkan.

Wawancara dengan Co-Founder Indonesia Guidelight Project, Nur Rizkya Hanifa pada hari Rabu, 21 Juli 2021, pukul 07.33 WIB.

Wawancara dengan Founder Indonesia Guidelight Project, Ahmad Safe'i Ridwan pada hari Kamis, 22 Juli 2021, pukul 10.13 WIB.

Wawancara dengan Haekal Maulana pada hari Senin, 26 Juli 2021 pukul 16.43 WIB.

Wawancara dengan Ibrahim M. Akadji pada hari Senin, 26 Juli 2021 pukul 16.55 WIB.

Wawancara dengan Vera Setianingsih pada hari Senin, 26 Juli 2021 pukul 17.45 WIB.

Wawancara dengan Ibrahim Hasan Ali pada hari Senin, 26 Juli 2021 pukul 19.01 WIB. 
Wawancara dengan Putri Retno Pambayun pada hari Senin, 26 Juli 2021 pukul 19.13 WIB.

Wawancara dengan Putri Retno Pambayun pada hari Senin, 26 Juli 2021 pukul 19.13 WIB.

Wawancara dengan Mufidah pada hari Senin, 26 Juli 2021 pukul 21.25 WIB.

Wawancara dengan Putri Retno Pambayun dan Rosyidatun Sholihah pada hari Senin, 26 Juli 2021.

Wawancara dengan Siti Uswatun Hasanah pada hari Selasa, 27 Juli 2021 pukul 11.23 WIB.

Wawancara dengan Ibrahim M. Akadji, Muhamad Ariz Pratama dan Ruri Alifia Ramadhani pada hari Senin 26 Juli 2021 hingga Kamis, 29 Juli 2021.

Wawancara dengan Mufidah dan Ahmad Fauzy Habibiy Prasetya pada hari Senin, 26 Juli 2021 hingga Kamis, 29 Juli 2021.

Wawancara dengan Mufidah, Nur Muhammad Khanif, Vera Setianingsih dan Ruliah Sari pada hari Senin, 26 Juli 2021 hingga Kamis, 29 Juli 2021.

Wawancara dengan Hafshah Farah Fadhilah, Siti Uswatun Khasanah, Nadya Ahyani, Nurul Ain Saraswati, Althaf Abrar Tianto, Nur Muhammad Khanif, Vera Setianingsih, Firda Shabrina, Muhammad Ichsan Rahman, Ruliah Sari, Rayhana Yamini, Armita Dwi Fairuz, Putri Retno Pambayun dan Faris Abdurrahman pada hari Senin, 26 Juli 2021 hingga Kamis, 29 Juli 2021.

Wawancara dengan Prasetyo Aji Laksono, Ruliah Sari, Nur Muhammad Khanif dan Rosyidatun Sholihah pada hari Senin, 26 Juli 2021 hingga Kamis, 29 Juli 2021.

Wawancara dengan Siti Uswatun Hasanah, Nur Muhammad Khanif, Ibrahim M. Akadji, Amna El Sayida, dan Mufidah pada hari Senin, 26 Juli 2021 hingga Kamis, 29 Juli 2021.

Wawancara dengan Vera Setianingsih, Ibrahim M. Akadji dan Armita Dwi Fairuz pada hari Senin, 26 Juli 2021 hingga Kamis, 29 Juli 2021.

Wawancara dengan Ibrahim M. Akadji, Vera Setianingsih, Putri Retno Pambayun dan Muhammad Husain pada Hari Senin, 26 Juli 2021 hingga Kamis, 29 Juli 2021.

Wawancara dengan Ibrahim M. Akadji, Siti Uswatun Hasanah, Nurul Ain Saraswati, Mufidah, Muhammad Husain, Armita Dwi Fairuz dan Faris Abdurrahman pada Hari Senin, 26 Juli 2021 hingga Kamis, 29 Juli 2021.

Wawancara dengan Muhammad Ichsan Rahman, Prasetyo Aji Laksono, Ruri Alifia Ramadhani, Rayhana Yamini dan Amna El Sayida pada hari Senin, 26 Juli 2021 hingga Kamis, 29 Juli 2021.

Wawancara Hafshah Farah Fadhilah dan Ibrahim M. Akadji pada hari Senin, 26 Juli 2021 hingga Kamis, 29 Juli 2021.

Wawancara dengan Amna El Sayida, Prasetyo Aji Laksono, Vera Setianingsih, Nadya Ahyani, Muhammad Husain, Ruri Alifia Ramadhani, Ibrahim Hasan Ali dan Putri Retno Pambayun pada hari Senin, 26 Juli 2021 hingga Kamis, 29 Juli 2021.

Wawancara dengan Firda Shabrina dan Ruliah Sari pada hari Senin, 26 Juli 2021 hingga Kamis, 29 Juli 2021. 
Indonesia Guidelight Project dan Tafsir Audiovisual: Tinjauan atas Metodologi Tafsir dan Kontribusinya di Masa Pandemi

Wawancara dengan Amna El Sayida pada hari Kamis, 29 Juli 2021 pukul 06.47 WIB.

Wawancara dengan Prasetyo Aji Laksono pada hari Kamis, 29 Juli 2021 pukul 08.43 WIB.

156 | Al-Fanar: Jurnal Ilmu Al-Qur'an dan Tafsir 